\title{
Growth and in-vitro metabolism of placental tissues of cows from Day 100 to Day 250 of gestation
}

\author{
L. P. Reynolds, D. S. Millaway, J. D. Kirsch, J. E. Infeld and D. A. Redmer
}

Department of Animal and Range Sciences, North Dakota State University, Fargo, North Dakota 58105, USA

\begin{abstract}
Summary. Weight of placental tissues of cows increased exponentially from Day 100 to Day 250 of gestation, but at much slower relative and absolute rates than fetal weight. In addition, growth rate of fetal placental tissues was less than that of maternal placental tissues. Concentrations of DNA, RNA and protein, however, increased in fetal placental but not in maternal placental tissues. Fetal placental tissues therefore exhibited hyperplasia, which probably contributes to increased functional capacity of the placenta during late gestation. The rate of $\mathrm{O}_{2}$ uptake in vitro was greatest for maternal placental tissues, suggesting that the maternal portion of the placenta accounts for most of the large rate of placental $\mathrm{O}_{2}$ utilization in vivo. Compared with other placental tissues, rate of secretion of macromolecules by intercaruncular endometrium was high, but decreased from Day 100 to 250 , suggesting that uterine glandular secretory activity may decrease as gestation advances. Rate of secretion of macromolecules also was high for intercotyledonary tissues and increased with day of gestation, suggesting a role for secretory products of chorioallantois in gravid uterine function.
\end{abstract}

Keywords: placenta; growth; metabolism; cow; gestation

\section{Introduction}

The mammalian placenta consists of fetal and maternal tissues and is the site of exchange of respiratory gases, nutrients and waste substances between the fetal and maternal systems (Barcroft, 1946; Ramsey, 1982). Normal growth and development of the placenta are therefore vital to normal fetal growth and development. It is well known that treatments which reduce fetal growth (e.g. maternal genotype, reduced uterine surface area per fetus, maternal nutrient deprivation, environmental heat stress) are associated with decreased placental size (Wallace, 1948; McKeown \& Record, 1953; Eckstein et al., 1955; Joubert \& Hammond, 1958; Alexander, 1964a, b; Bell et al., 1987). In addition, in normal pregnancy placental and fetal weights are highly correlated (Eckstein et al., 1955; Alexander, 1964a; Anthony et al., 1986). Size of the placenta and its blood supply are primary determinants of the rate of physiological exchange between the fetal and maternal systems (Reynolds et al., 1985a, b, 1986; Bell et al., 1986, 1987; Reynolds \& Ferrell, 1987). Conditions associated with reduced rate of fetal growth also are associated with reduced rates of placental blood flow and reduced fetal $\mathrm{O}_{2}$ and nutrient uptakes (Wootton et al., 1977; Reynolds et al., 1985a, b; Bell et al., 1987; Ferrell \& Reynolds, 1987). Therefore, factors which influence placental growth and development will probably have a substantial influence on fetal growth and development. Before the relationships between fetal and placental growth can be determined, however, an understanding of normal placental growth must be obtained.

The ruminant placenta is divided into placentomes comprising maternal caruncular endometrium and fetal cotyledon, and also into interplacentomal areas comprising intercaruncular endometrium 
and intercotyledonary fetal membrane (Ramsey, 1982). Growth of these placental tissues, however, has not been well characterized in cows. Prior \& Laster (1979) measured weights and surface areas for cotyledons and placenta (defined as fetal membranes with cotyledons removed) of cows, but did not report weights or surface areas of maternal caruncles. Ferrell et al. (1976a) reported weights of fetal membranes (presumably including fetal cotyledons) at several stages of gestation, but found growth rate of fetal membranes to be about half that observed by Prior \& Laster (1979). Anthony et al. (1986) reported a 2-fold increase in total placentomal weight from Day 200 to 260 of gestation. Additionally, we are not aware of any reports which describe gestational changes in cellular composition (DNA, RNA and protein contents) of placental tissues in cows. An important consideration in describing the relationship between fetal and placental growth is the high metabolic rate exhibited by the placenta. Indeed, major portions $\left(60-80 \%\right.$ at midgestation) of $\mathrm{O}_{2}$ and nutrients taken up by the gravid uterus are utilized by the placenta, which has a high rate of metabolism compared with other gravid uterine or maternal tissues (Meschia et al., 1966; Reynolds et al., 1986; Bell et al., 1986). Which of the placental tissues accounts for this high metabolic activity, however, has not been determined.

The objectives of the present study were to determine the relationship between fetal and placental growth, and to characterize cellular growth and metabolism of individual components of the placenta at several stages of gestation in cows.

\section{Materials and Methods}

Hereford and Hereford-cross cows were mated with Hereford bulls (Day 0 of gestation) and fed alfalfa/grass hay at a level calculated to maintain body weight, with free access to salt and mineral supplements. The 21 cows were assigned randomly to slaughter on approximately Days $100(103 \pm 0 \cdot 7, \mathrm{~N}=4), 150(151 \pm 0 \cdot 5, \mathrm{~N}=5), 200(200 \pm 1 \cdot 2$, $\mathrm{N}=6)$ and $250(250 \pm 0.5, \mathrm{~N}=6)$ of gestation. For each cow, the entire gravid uterus (from mid-cervix to both utero-tubal junctions) was obtained. For 9 cows ( 2 at Day 150, 4 at Day 200 and 3 at Day 250 ), a sample $(\approx 2 \mathrm{~g})$ of maternal liver was also obtained. Gravid uteri and maternal liver samples were immediately transported to the laboratory (within $10 \mathrm{~min}$ after collection and within $30 \mathrm{~min}$ after slaughter).

Weights of gravid uterine tissues. At the laboratory, the entire gravid uterus of each cow was weighed and fetus, fetal membranes and uterus were separated. Cotyledons were carefully dissected from fetal membranes. Caruncles were dissected from the uterine luminal surface, taking care not to include intercaruncular tissue. Any cotyledonary villi remaining in caruncular crypts were removed with forceps and included with cotyledons. Weights of fetus, uterus (minus caruncles), total caruncles, total cotyledons and total fetal membranes (chorioallantois plus amnion) were determined. Weight of fetal fluids was calculated as gravid uterine weight minus total weights of gravid uterine tissues (fetus + uterus + caruncles + cotyledons + fetal membranes). Placentomal weight was calculated as the sum of caruncular and cotyledonary weights. Weights of tissue samples obtained for evaluation of cellular growth, metabolic rate and $\left[{ }^{3} \mathrm{H}\right]$ leucine incorporation (see below) were included with the appropriate tissue weight. Curved crown-rump lengths of fetuses were determined as described by Ferrell et al. (1976a).

DNA, RNA and protein concentrations. To evaluate cellular growth of placental tissues, samples $(\approx 2 \mathrm{~g})$ of caruncular, intercaruncular, cotyledonary and intercotyledonary (chorioallantoic) tissues were obtained from the middle portion (near the fetus) of the gravid uterine horn of each cow and stored frozen at $-80^{\circ} \mathrm{C}$. Approximately $1 \mathrm{~g}$ of each tissue sample was homogenized in PBS-EDTA buffer $(0 \cdot 01 \mathrm{M}$-sodium phosphate, $0 \cdot 14 \mathrm{M}-\mathrm{NaCl}, 3 \mathrm{~mm}-\mathrm{NaN}$, 1 mM-EDTA, pH 7.3) by using a Polytron (Brinkmann, Westbury, NY, USA). Tissue homogenates were analysed for concentrations of DNA and RNA by using diphenylamine and orcinol procedures, respectively, as described previously (Reynolds et al., 1985a). Standards were DNA Type I from calf thymus and RNA Type IV from calf liver (both from Sigma, St Louis, MO, USA). Concentrations of protein in tissue homogenates were determined by the method of Lowry et al. (1951) with bovine serum albumin (Fraction V, Sigma) as standard. Concentration and total content of DNA were used as indexes of hyperplasia, and ratios of RNA:DNA and protein:DNA were used as indexes of tissue hypertrophy (Enesco \& Leblond, 1962; Rattray et al., 1975). For caruncular and cotyledonary tissues, total content of DNA, RNA and protein were determined by multiplying concentrations in tissue samples by total tissue weight.

Oxygen consumption. To evaluate metabolic rate of placental tissues, samples $(\approx 1 \mathrm{~g})$ of caruncular, intercaruncular, cotyledonary and intercotyledonary (chorioallantoic) tissues were obtained from the middle portion (near the fetus) of the gravid uterine horn of each cow, and samples of maternal liver were obtained from 9 of the cows. Tissue samples were sliced by using a Stadie-Riggs microtome (Thomas, Philadelphia, PA, USA), and slices ( $0.5 \mathrm{~mm}$ thick, $66.6 \pm 1.4 \mathrm{mg}$ ) were placed into $35-\mathrm{mm}$ Petri dishes containing $3 \mathrm{ml} \mathrm{Krebs'-Ringer} \mathrm{buffer} \mathrm{(37}{ }^{\circ} \mathrm{C}$ ) of the following composition (mM): $\mathrm{NaCl}, 118 \cdot 1 ; \mathrm{NaHCO}_{3}, 25 \cdot 0 ; \mathrm{KCl}, 4 \cdot 7 ; \mathrm{CaCl}_{2}, 2 \cdot 5 ; \mathrm{KH}_{2} \mathrm{PO}_{4}, 1 \cdot 2 ; \mathrm{MgSO}_{4}, 1 \cdot 2 ; \mathrm{glucose}$ 
$11 \cdot 1$ (Reynolds \& Ford, 1984). Tissue slices were weighed on a torsion balance (Roller-Smith, Bethlehem, PA, USA), and placed into a stirred-cell $\mathrm{O}_{2}$ consumption monitor with a Clark-type polarographic electrode (model 5300, Yellow Springs Instruments, Yellow Springs, OH, USA). Oxygen consumption of tissue slices was monitored for $5 \mathrm{~min}$ in $1 \mathrm{ml}$ of $\mathrm{O}_{2}$ consumption buffer (Krebs'-Ringer buffer containing $5.0 \mathrm{~mm}$-sodium pyruvate, $5.0 \mathrm{~mm}$-sodium glutamate, $4.5 \mathrm{~mm}$-sodium acetate and $4.5 \mathrm{~mm}$-malic acid; Ferrell et al., 1976b) at $37^{\circ} \mathrm{C}$ and recorded on a chart recorder. To minimize time effects, all tissues were analysed within $4 \mathrm{~h}$ after collection and in random order. Available $\mathrm{O}_{2}$ in solution was assumed to be $224 \mathrm{nmol} / \mathrm{ml} \mathrm{Krebs'-Ringer} \mathrm{buffer} \mathrm{at} 760 \mathrm{mmHg}$ and $37^{\circ} \mathrm{C}$ (Umbriet et al., 1972) and was adjusted daily for barometric pressure, which was determined in the laboratory by using a mercury barometer. Oxygen consumption was calculated as percentage utilization of available $\mathrm{O}_{2}$ and is reported as $\mu \mathrm{mol} \cdot \mathrm{min}^{-1} \cdot \mathrm{g}$ tissue $^{-1}$

Incorporation of $\left.l^{3} \mathrm{H}\right]$ leucine into macromolecules. To evaluate rate of synthesis/secretion of macromolecules, samples $(\approx 1 \mathrm{~g})$ of caruncular, intercaruncular, cotyledonary and intercotyledonary (chorioallantoic) tissues were obtained, as above, from the middle portion of the gravid uterine horn of each cow. Explants $(175.7 \pm 7.4 \mathrm{mg})$ of these tissues were incubated for $24 \mathrm{~h}$ in $10 \cdot \mathrm{ml}$ low-leucine Eagle's MEM containing $\approx 20 \mu \mathrm{Ci}(17.6 \pm 0.3 \mu \mathrm{Ci}$; $293 \cdot 7 \pm 4 \cdot 3 \mathrm{pmol})\left[{ }^{3} \mathrm{H}\right]$ leucine $\left(1-\left[4,5-{ }^{3} \mathrm{H}(\mathrm{N})\right]\right.$ leucine: New England Nuclear, Boston, MA, USA), as described previously (Bartol et al., 1985a, b; Millaway et al., 1989). After incubation, duplicate $0.25 \mathrm{ml}$ aliquants of media were diluted with $1.75 \mathrm{ml}$ distilled $\mathrm{H}_{2} \mathrm{O}$ and dialysed (SpectraPor $6,1000 M_{\mathrm{r}}$ cutoff, Spectrum, Los Angeles, CA, USA) against 1000 volumes phosphate-buffered saline $(\mathrm{pH} 7.4)$ at $4^{\circ} \mathrm{C}$, as described by Millaway et al. (1989). Radioactivity remaining after dialysis was determined by liquid scintillation counting of $0.5 \mathrm{ml} \mathrm{samples}$ of retentates. To determine rate of synthesis/secretion of macromolecules, duplicate explants $(185.7 \pm 17.1 \mathrm{mg})$ of placental tissues were obtained from 2 additional cows (Days 197 and 202 of gestation) and incubated as described above. Samples (0.25 ml) of media from these explant incubations were obtained at 8,16 and $24 \mathrm{~h}$ of incubation, diluted, dialysed and counted for radioactivity as described above. Data are reported as pmol $\left[{ }^{3} \mathrm{H}\right]$ leucine incorporated into non-dialysable macromolecules per unit time per gram of tissue.

Statistical analysis. To describe growth of gravid uterine tissues, an exponential growth model was used:

$$
\mathrm{W}=\mathrm{W}_{0} \mathrm{e}^{(\mathrm{b} 1+\mathrm{b} 2 \mathrm{t}) t}
$$

where $W=$ weight in grams, $W_{0}=$ initial weight in grams at Day 0 of gestation, $b l=$ initial growth rate, $\mathrm{b} 2=$ change in growth rate and $\mathrm{t}=$ day of gestation (Koong et al., 1975; Ferrell et al., 1976a; SAS, 1985). This exponential model also was used to describe total contents of DNA, RNA and protein in caruncular and cotyledonary tissues, except that content in milligrams was used instead of weight in grams. For curved crown-rump length, linear regression on day of gestation was used. Least-squares (General Linear Models) analysis of variance was used to determine differences in DNA, RNA and protein concentrations and ratios, $\mathrm{O}_{2}$ consumption rates, and $\left[{ }^{3} \mathrm{H}\right]$ leucine incorporation rates of placental tissues, with day of gestation, tissue and day $\times$ tissue interaction included in the model (SAS, 1985). When a main effect or interaction F-test was significant $(P<0.05)$, differences between specific means were determined by using Bonferroni's $t$ test (Kirk, 1968). Data are reported as means \pm s.e.m.

\section{Results}

\section{Weights of gravid uterine tissues}

Weights of gravid uterine tissues and fetal fluids, and also curved crown-rump lengths, are given in Table 1. Weights of all the gravid uterine tissues increased exponentially $(P<0.01)$ from Day 100 to Day 250 of gestation, and the model used to describe growth of these tissues explained a large proportion of the variation in weights $\left(\mathrm{R}^{2}=0.80-0.98\right.$; Table 2 , Fig. 1a and $\left.1 \mathrm{~b}\right)$. Although weight of fetal fluids also increased exponentially $(P<0.02)$, the model explained only $26 \%$ of variation in fetal fluid weight (Table 2). Curved crown-rump length increased as a linear function of day of gestation [curved crown-rump $(\mathrm{cm})=-21.032+0.457$ (day of gestation), $\mathrm{R}^{2}=0.96$, $\mathrm{N}=21, P<0.01]$.

The initial rate of increase in fetal weight was $8.02 \%$ per day, and this rate decreased by $0.014 \%$ per day as gestation advanced (Fig. 1a). This model agrees with the data of Koong et al. (1975) for sheep and Ferrell et al. (1976a) for cattle, who also reported a decrease in relative rate (\%/day) of fetal growth as gestation progressed. Although relative rate decreased, absolute rate $(\mathrm{kg} / \mathrm{day})$ of fetal growth continued to increase throughout gestation because of increasing fetal mass. Thus, in the present study, increase in fetal weight from Days 100 to 150,150 to 200 and 200 to 250 of gestation was 816,407 and $220 \%$ on a relative basis but $2 \cdot 72,9 \cdot 53$ and $15 \cdot 12 \mathrm{~kg}$ on an absolute basis (Table 1). The initial rate of increase in placentomal (caruncular + cotyledonary) weight was $6.16 \%$ per day, which decreased by $0.012 \%$ per day thereafter (Fig. la). Because the relative rate of 
Table 1. Weights (means \pm s.e.m.) of gravid uterine tissues of cows

\begin{tabular}{|c|c|c|c|c|}
\hline \multirow{2}{*}{$\begin{array}{l}\text { Tissue wt } \\
(\mathrm{kg})\end{array}$} & \multicolumn{4}{|c|}{ Day of gestation } \\
\hline & 100 & 150 & 200 & 250 \\
\hline Gravid uterus & $3 \cdot 61 \pm 0 \cdot 16$ & $12.73 \pm 0.56$ & $28.79 \pm 1.59$ & $47.34 \pm 3.64$ \\
\hline Uterus & - & $1.99 \pm 0.13$ & $3.75 \pm 0.20$ & $4 \cdot 28 \pm 0 \cdot 32$ \\
\hline Fetus & $0.38 \pm 0.01$ & $3 \cdot 10 \pm 0 \cdot 11$ & $12.63 \pm 0.38$ & $27.75 \pm 2.13$ \\
\hline Fetal membranes & $0.25 \pm 0.02$ & $0.46 \pm 0.03$ & $1.15 \pm 0.77$ & $1.45 \pm 0.92$ \\
\hline Fetal fluids & 二 & $6.01 \pm 0.45$ & $7.86 \pm 1.07$ & $9.05 \pm 0.85$ \\
\hline Caruncles & $0.13 \pm 0.001$ & $0.71 \pm 0.05$ & $2 \cdot 12 \pm 0.14$ & $3.11 \pm 0.29$ \\
\hline Cotyledons & $0.16 \pm 0.01$ & $0.46 \pm 0.03$ & $1.28 \pm 0.11$ & $1.69 \pm 0.28$ \\
\hline $\begin{array}{l}\text { Curved crown-rump } \\
\text { length }(\mathrm{cm})\end{array}$ & $23.0 \pm 1.0$ & $48.5 \pm 0.8$ & $75 \cdot 6 \pm 1 \cdot 3$ & $90 \cdot 1 \pm 2 \cdot 4$ \\
\hline
\end{tabular}

Numbers of observations were 4 on Day 100, 5 on Day 150, 6 on Day 200 and 6 on Day 250 of gestation for all tissue weights and also for curved crown-rump length.

Table 2. Relationships between weights ( $\mathrm{g}$ ) of some components of the gravid uterus and day of gestation $(t)$ in cows

\begin{tabular}{llcc}
\hline \multicolumn{1}{c}{ Component } & \multicolumn{1}{c}{$\begin{array}{c}\text { Exponential } \\
\text { equation }\end{array}$} & $\begin{array}{c}\text { Coefficient of } \\
\text { determination }\left(\mathrm{R}^{2}\right)\end{array}$ & $\begin{array}{c}\text { Coefficient of } \\
\text { variation }(\%)\end{array}$ \\
\hline Gravid uterus & $\mathrm{W}=71 \cdot 228 \mathrm{e}^{(0.0468-0.0000838) t}$ & 0.98 & 1.5 \\
Uterus & $\mathrm{W}=11.257 \mathrm{e}^{(0.0503-0.0001064) \mathrm{t}}$ & 0.80 & 2.0 \\
Fetal membranes & $\mathrm{W}=19.387 \mathrm{e}^{(0.0289-0.00004621) !}$ & 0.92 & $3 \cdot 0$ \\
Fetal fluids & $\mathrm{W}=3257.09 \mathrm{e}^{0.00405 t}$ & 0.26 & $2 \cdot 9$ \\
\hline
\end{tabular}

Significance of exponential regressions: $P<0 \cdot 01$ for gravid uterus, uterus and fetal membranes, and $P<0.02$ for fetal fluids. Numbers of observations were 21 for gravid uterus and fetal membranes, and 17 for uterus and fetal fluids. Regressions of uterine and fetal fluid weights include only data from Day 150 to Day 250 since data for these components were not obtained on Day 100 (Table 1).

increase of fetal weight was greater than that of placentomal weight, fetal weight increased 73-fold whereas placentomal weight increased only 16-fold from Day 100 to 250 of gestation (Table 1; Fig. 1a). Thus, although fetal and placentomal weights were similar at Day 100 of gestation $(0 \cdot 38$ and $0.29 \mathrm{~kg}$, respectively), by Day 250 fetal weight was 6-fold greater than placentomal weight (Table 1 , Fig. 1a). Similarly, because of a difference in relative rate of increase in weight of maternal caruncules and fetal cotyledons, these components of the placentome exhibited differential growth (Fig. 1b). Although their weights were similar at Day 100, caruncular weight was 2-fold greater than cotyledonary weight by Day 250 of gestation (Table 1, Fig. 1b). Although caruncular and cotyledonary tissues cannot be separated with $100 \%$ efficiency, our experience suggests that only a relatively small amount of fetal cotyledonary tissue remains in maternal caruncular crypts when these tissues are carefully separated, and we have substantiated this observation histologically (Reynolds \& Redmer, 1988). It therefore seems unlikely that the 2-fold difference between caruncular and cotyledonary weights at Day 250 could be explained by poor efficiency of separation of these tissues.

\section{DNA, RNA and protein concentrations}

Concentrations and ratios of DNA, RNA and protein in placental tissues are given in Table 3.

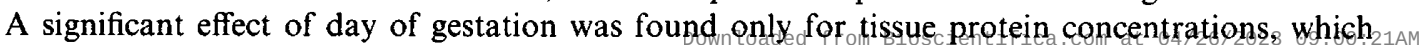



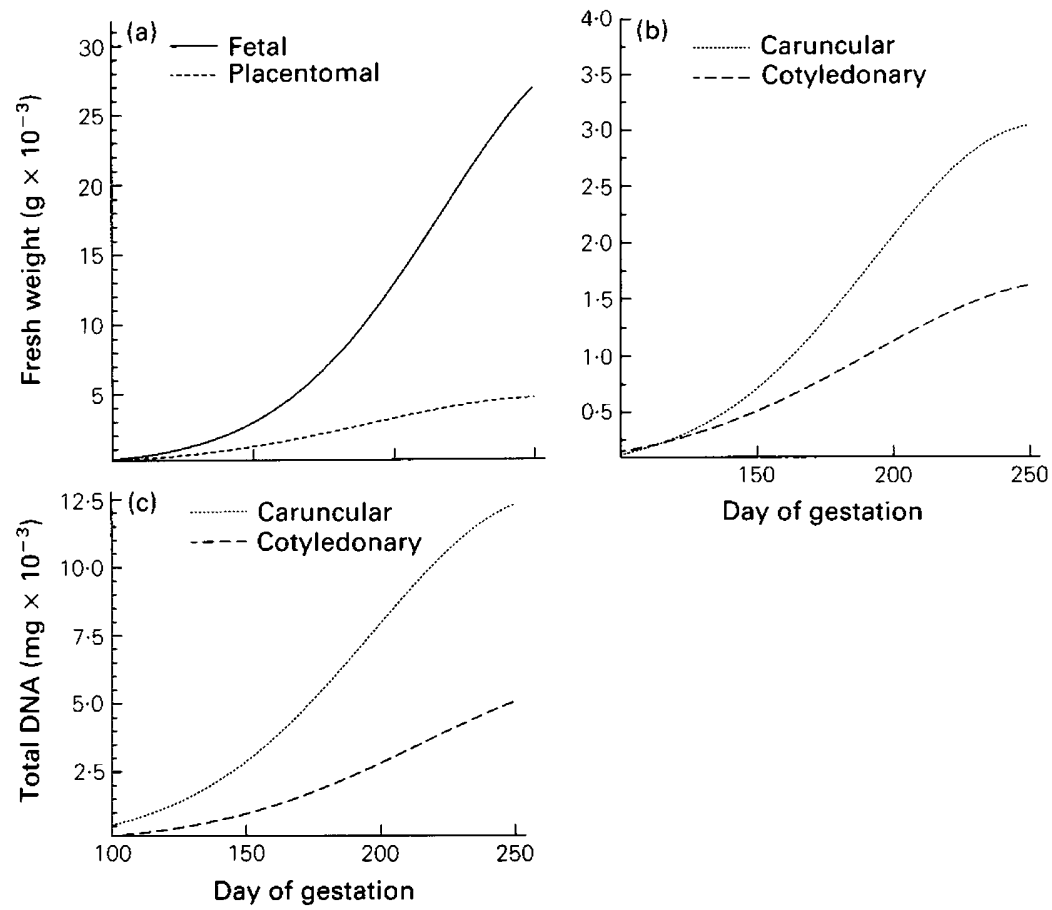

Day of gestation

Fig. 1. Relationships of tissue weights (g) with day of gestation $(\mathrm{t})$ in cows. Exponential regressions: (a) fetal weight $=0.463 \mathrm{e}^{(0.0802-0.0001452 t) t}, \mathrm{R}^{2}=0.99, \mathrm{~N}=21, \mathrm{C} . \mathrm{V} .=1.6 \%$, $P<0.01$; and placentomal weight $=1.757 \mathrm{e}^{(0.0616-0.0001203 t) t}, \mathrm{R}^{2}=0.97, \mathrm{~N}=21, \mathrm{C} . \mathrm{V} .=$ $2.5 \%, P<0.01$. (b) caruncular weight $=0.532 \mathrm{e}^{(0.0682-0.0001343 t) t}, \mathrm{R}^{2}=0.98, \quad \mathrm{~N}=21$, C.V. $=2.6 \%, P<0.01 ;$ and cotyledonary weight $=3.680 \mathrm{e}^{(0.0458-0.0000859 \mathrm{t}) \mathrm{t}}, \mathrm{R}^{2}=0.91$, $\mathrm{N}=21$, C.V. $=4.2 \%, P<0.01$. (c) caruncular DNA content $=5.347 \mathrm{e}^{(0.0589-0.0001115 t)}$, $\mathrm{R}^{2}=0.94, \quad \mathrm{~N}=21, \quad \mathrm{C} . \mathrm{V} .=3.4 \%, \quad P<0.01 ; \quad$ and cotyledonary DNA content $=$ $3.422 \mathrm{e}^{(0.0515-0.0000891 \mathrm{t}) \mathrm{t}}, \mathrm{R}^{2}=0.89, \mathrm{~N}=21, \mathrm{C} . \mathrm{V} .=5.6 \%, P<0.01$.

increased $(P<0.01)$ from Day 100 to 250 . When averaged across all days of gestation, concentrations of DNA, RNA and protein $(\mathrm{mg} / \mathrm{g}$ tissue) were greater $(P<0.01)$ in caruncular $(4.31 \pm 0.22,3.88 \pm 0.12$ and $51.1 \pm 1.4)$ than in intercaruncular $(2.70 \pm 0.22,1.85 \pm 0.14$ and $37.2 \pm 2.2)$ or cotyledonary $(2.54 \pm 0.21,1.79 \pm 0.19$ and $36.4 \pm 2.9)$ tissues, and were greater $(P<0.01)$ in intercaruncular and cotyledonary than in intercotyledonary $(1.62 \pm 0.21$, $1.24 \pm 0.16$ and $22.7 \pm 1.9)$ tissues (Table 3). Additionally, significant $(P<0.01)$ day $\times$ tissue interactions were observed for DNA, RNA and protein concentrations of placental tissues. Concentrations of DNA, RNA and protein remained constant across day of gestation in caruncular and intercaruncular tissues. For cotyledonary and intercotyledonary tissues, however, concentrations of DNA, RNA and protein increased $(P<0.01)$ from Day 100 to 250 of gestation. As mentioned above, rate of increase in cotyledonary weight was less than that of caruncular weight. However, since concentrations of DNA increased 2-fold in cotyledonary tissues while remaining constant in caruncular tissues, the rate of increase of total DNA was similar for cotyledonary and caruncular tissues (Fig. 1c). The ratio of cotyledonary to caruncular DNA therefore remained constant across day of gestation, averaging $0.39 \pm 0.02$ (Fig. 1c). Similarly, because concentrations of RNA and protein in cotyledonary tissues increased 3-fold across gestation, rates of increase of total tissue RNA and protein also were comparable for cotyledonary and caruncular tissues (data not shown). These differences in cellular growth of maternal and fetal placentomal tissues also were observed for interplacentomal tissues, with intercotyledonary tissues exhibiting 3 -4nfold increases $_{09}: 00: 21 \mathrm{AM}$ 
in DNA, RNA and protein concentrations, whereas concentrations of DNA, RNA and protein in intercaruncular tissues remained constant from Day 100 to 250. Ratios of RNA:DNA and protein:DNA remained constant across day of gestation for all placental tissues, and no day $\times$ tissue interaction was observed. When averaged across all days of gestation, ratio of RNA:DNA was greatest $(P<0.05)$ in caruncular $(0.94 \pm 0.05)$, intermediate in intercotyledonary $(0.82 \pm 0.08)$ and least $(P<0.05)$ in intercaruncular and cotyledonary $(0.73 \pm 0.05$ and $0.74 \pm 0.09)$ tissues (Table 3). Protein:DNA ratio was greater $(P<0.05)$ in intercotyledonary $(16.7 \pm 1.5)$ than in caruncular $(12.4 \pm 0.6)$ tissues, and was intermediate in intercaruncular and cotyledonary $(15 \cdot 3 \pm 1 \cdot 5$ and $15 \cdot 3 \pm 1 \cdot 4)$ tissues (Table 3$)$.

Table 3. Mean \pm s.e.m. DNA, RNA and protein concentrations and ratios in placental tissues of cows

\begin{tabular}{|c|c|c|c|c|c|c|}
\hline Tissue & $\begin{array}{l}\text { Day of } \\
\text { gestation }\end{array}$ & $\begin{array}{l}\text { DNA } \\
(\mathrm{mg} / \mathrm{g})\end{array}$ & $\begin{array}{l}\text { RNA } \\
(\mathrm{mg} / \mathrm{g})\end{array}$ & $\begin{array}{l}\text { Protein } \\
(\mathrm{mg} / \mathrm{g})\end{array}$ & RNA:DNA & Protein:DNA \\
\hline Caruncle & $\begin{array}{l}100 \\
150 \\
200 \\
250\end{array}$ & $\begin{array}{l}4.88 \pm 0.35 \\
4.55 \pm 0.52 \\
3.77 \pm 0.37 \\
4.25 \pm 0.44\end{array}$ & $\begin{array}{l}4.16 \pm 0.26 \\
4.09 \pm 0.18 \\
3.46 \pm 0.20 \\
3.92 \pm 0.27\end{array}$ & $\begin{array}{l}49.9 \pm 6.2 \\
51.9 \pm 2.3 \\
47.5 \pm 2.2 \\
54.7 \pm 0.8\end{array}$ & $\begin{array}{l}0.86 \pm 0.05 \\
0.94 \pm 0.09 \\
0.97 \pm 0.11 \\
0.96 \pm 0.11\end{array}$ & $\begin{array}{l}10 \cdot 1 \pm 0 \cdot 7 \\
11 \cdot 9 \pm 1 \cdot 1 \\
13 \cdot 2 \pm 1 \cdot 3 \\
13 \cdot 5 \pm 1 \cdot 2\end{array}$ \\
\hline $\begin{array}{r}\text { Intercaruncular } \\
\text { endometrium }\end{array}$ & $\begin{array}{l}100 \\
150 \\
200 \\
250\end{array}$ & $\begin{array}{l}2.66 \pm 0.53 \\
2.23 \pm 0.27 \\
2.87 \pm 0.34 \\
2.94 \pm 0.60\end{array}$ & $\begin{array}{l}2.10 \pm 0.46 \\
1.64 \pm 0.34 \\
1.90 \pm 0.15 \\
1.80 \pm 0.29\end{array}$ & $\begin{array}{l}31 \cdot 6 \pm 10 \cdot 2 \\
36 \cdot 7 \pm 2 \cdot 5 \\
39 \cdot 2 \pm 3 \cdot 1 \\
39 \cdot 4 \pm 2 \cdot 1\end{array}$ & $\begin{array}{l}0.90 \pm 0.14 \\
0.75 \pm 0.14 \\
0.70 \pm 0.10 \\
0.65 \pm 0.08\end{array}$ & $\begin{array}{l}11 \cdot 7 \pm 4 \cdot 5 \\
17.9 \pm 3 \cdot 4 \\
14 \cdot 6 \pm 2.2 \\
16 \cdot 1 \pm 3 \cdot 0\end{array}$ \\
\hline Cotyledon & $\begin{array}{l}100 \\
150 \\
200 \\
250\end{array}$ & $\begin{array}{l}1.56 \pm 0.32 \\
2 \cdot 48 \pm 0.24 \\
2 \cdot 39 \pm 0.40 \\
3.39 \pm 0.31\end{array}$ & $\begin{array}{l}0.76 \pm 0.20 \\
1.30 \pm 0.13 \\
2.03 \pm 0.29 \\
2.65 \pm 0.26\end{array}$ & $\begin{array}{l}17.1 \pm 2.0 \\
29.1 \pm 1.0 \\
40.4 \pm 2.9 \\
51.3 \pm 1 \cdot 3\end{array}$ & $\begin{array}{l}0.49 \pm 0.10 \\
0.53 \pm 0.06 \\
1.02 \pm 0.29 \\
0.78 \pm 0.04\end{array}$ & $\begin{array}{l}11.6 \pm 1.4 \\
12.1 \pm 1.1 \\
19.7 \pm 3.8 \\
16.0 \pm 1.9\end{array}$ \\
\hline $\begin{array}{c}\text { Intercotyledonary } \\
\text { chorioallantois }\end{array}$ & $\begin{array}{l}100 \\
150 \\
200 \\
250\end{array}$ & $\begin{array}{l}0.66 \pm 0.28 \\
1.40 \pm 0.18 \\
2.05 \pm 0.51 \\
2.03 \pm 0.32\end{array}$ & $\begin{array}{l}0.36 \pm 0.10 \\
1.30 \pm 0.30 \\
1.47 \pm 0.24 \\
1.55 \pm 0.28\end{array}$ & $\begin{array}{r}7.8 \pm 1.4 \\
23.2 \pm 2.0 \\
24.8 \pm 1.6 \\
30.0 \pm 1.6\end{array}$ & $\begin{array}{l}0.79 \pm 0.26 \\
0.91 \pm 0.17 \\
0.82 \pm 0.16 \\
0.76 \pm 0.08\end{array}$ & $\begin{array}{l}18 \cdot 4 \pm 5 \cdot 7 \\
18 \cdot 3 \pm 3 \cdot 4 \\
14 \cdot 6 \pm 2 \cdot 1 \\
16 \cdot 4 \pm 2 \cdot 2\end{array}$ \\
\hline
\end{tabular}

Numbers of observations were 4 on Day 100, 5 on Day 150, 6 on Day 200 and 6 on Day 250 for all tissues.

\section{Oxygen consumption}

Day of gestation had no significant effect on $\mathrm{O}_{2}$ consumption of placental tissues, and no day $\times$ tissue interaction was found. Oxygen consumption differed, however, among placental tissues (Table 4). Across all days of gestation, $\mathrm{O}_{2}$ uptake $\left(\mu \mathrm{mol} \cdot \mathrm{min}^{-1} \cdot \mathrm{g}\right.$ tissue ${ }^{-1}$ ) of intercaruncular tissues $(0.37 \pm 0.02)$ was greater $(P<0.01)$ than that of other placental tissues. In addition, $\mathrm{O}_{2}$ uptake of caruncular tissues across gestation $(0.30 \pm 0.02)$ was greater than that of cotyledonary and intercotyledonary tissues $(0 \cdot 10 \pm 0.01$ and $0.15 \pm 0.01)$ which were similar.

\section{Incorporation of $\left[{ }^{3} \mathrm{H}\right]$ leucine into macromolecules}

For all tissues, rate of incorporation of $\left[{ }^{3} \mathrm{H}\right]$ leucine into non-dialysable macromolecules was linear from 8 to $24 \mathrm{~h}$ of culture (regressions, where $y=\mathrm{pmol} / \mathrm{g}$ tissue and $x=$ time in hours: caruncular incorporation $=-0.587+0.1312 x, \mathrm{R}^{2}=0.44, P<0.05$; intercaruncular incorporation $=1.682+1.8169 x, \mathrm{R}^{2}=0.34, P<0.10 ;$ cotyledonary incorporation $=-1.965+0.5936 x$, $\mathrm{R}^{2}=0.52, \quad P<0.01 ;$ and intercotyledonary incorporation $=0.756+0.3478 x, \quad \mathrm{R}^{2}=0.29$, $P<0 \cdot 10$ ). Incorporation of $\left[{ }^{3} \mathrm{H}\right]$ leucine by placental tissues did not vary across day of gestation. Significant differences $(P<0.01)$ in incorporation of $\left[{ }^{3} \mathrm{H}\right]$ leucine into secreted macromolecules were found, however, among placental tissues, and a day of gestation $\times$ tissue interaction

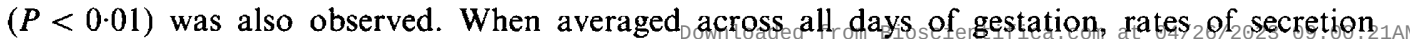


Table 4. Mean \pm s.e.m. oxygen consumption $\left(\mu \mathrm{mol} \cdot \mathrm{min}^{-1} \cdot \mathrm{g}\right.$ tissue $\left.{ }^{-1}\right)$ of placental tissues of cows

\begin{tabular}{|c|c|c|c|c|}
\hline \multirow[b]{2}{*}{ Tissue } & \multicolumn{4}{|c|}{ Day of gestation } \\
\hline & 100 & 150 & 200 & 250 \\
\hline Caruncle & $0.20 \pm \frac{ \pm}{(3)} 0.07$ & $0.29 \pm 0.03$ & $0 \cdot 32 \pm \frac{ \pm 0.04}{(6)}$ & $0.33 \underset{(6)}{ \pm} 0.06$ \\
\hline $\begin{array}{r}\text { Intercaruncular } \\
\text { endometrium }\end{array}$ & $0.30 \pm 0.08$ & $0.39 \pm 0.04$ & $0 \cdot 40 \pm 0.04$ & $0.37 \underset{(6)}{ \pm 0.04}$ \\
\hline Cotyledon & $0.14 \underset{(2)}{ \pm 0.04}$ & $0.08 \underset{(5)}{ \pm} 0.01$ & $0 \cdot 10 \pm 0.01$ & $0 \cdot 10 \pm 0.01$ \\
\hline $\begin{array}{l}\text { Intercotyledonary } \\
\text { chorioallantois }\end{array}$ & $0.14 \underset{(2)}{ \pm 0.06}$ & $0 \cdot 11 \underset{(5)}{ \pm} 0 \cdot 01$ & $0 \cdot 14 \underset{(6)}{ \pm 0} 0.02$ & $0.21 \pm 0.02$ \\
\hline
\end{tabular}

of macromolecules (pmol $24 \mathrm{~h}^{-1} \cdot \mathrm{g}$ tissue ${ }^{-1}$ ) by intercaruncular and intercotyledonary tissues $(31.3 \pm 4.8$ and $31.3 \pm 3.0)$ were greater $(P<0.01)$ than that of cotyledonary tissues $(21.0 \pm 1.9$; Table 5). In addition, secretory rate of cotyledonary tissues was greater $(P<0.01)$ than that of caruncular tissues (6.2 $\pm 0 \cdot 8$; Table 5). Rate of secretion of macromolecules by caruncules and cotyledons remained constant across day of gestation. Rate of secretion of macromolecules by intercaruncular endometrium, however, decreased $(P<0.01)$, whereas that of intercotyledonary chorioallantois increased $(P<0.05)$ from Day 100 to Day 250 of gestation (Table 5).

Table 5. Mean \pm s.e.m. incorporation of $\left[{ }^{3} \mathrm{H}\right]$ leucine into macromolecules by placental tissues of cows*

\begin{tabular}{|c|c|c|c|c|}
\hline \multirow[b]{2}{*}{ Tissue } & \multicolumn{4}{|c|}{ Day of gestation } \\
\hline & 100 & 150 & 200 & 250 \\
\hline Caruncle & $7 \cdot 2 \pm 2 \cdot 0$ & $8 \cdot 0 \pm 2 \cdot 0$ & $4 \cdot 1 \pm 1 \cdot 0$ & $6 \cdot 0 \pm 1 \cdot 3$ \\
\hline $\begin{array}{r}\text { Intercaruncular } \\
\text { endometrium }\end{array}$ & $49 \cdot 0 \pm 22.8$ & $35 \cdot 2 \pm 6 \cdot 1$ & $26 \cdot 8 \pm 4 \cdot 0$ & $20.8 \pm 1.5$ \\
\hline Cotyledon & $18 \cdot 8 \pm 5 \cdot 6$ & $21 \cdot 2 \pm 4 \cdot 3$ & $20 \cdot 7 \pm 4 \cdot 2$ & $22 \cdot 5 \pm 2 \cdot 5$ \\
\hline $\begin{array}{l}\text { Intercotyledonary } \\
\text { chorioallantois }\end{array}$ & $16.5 \pm 6.4$ & $33 \cdot 4 \pm 5 \cdot 1$ & $35.7 \pm 5.4$ & $35 \cdot 2 \pm 4.9$ \\
\hline
\end{tabular}

\section{Discussion}

Although placentomal weight increased exponentially throughout gestation, the absolute rate of increase was much less than that of fetal weight. In the ewe, placental weight ceases to increase or even decreases after Day 90 of gestation (Barcroft, 1946; Wallace, 1948; Alexander, 1964a). A similar pattern of continued growth of the fetus, but limited placental growth during the last half of gestation has been observed in several other mammalian species (Ibsen, 1928; Warwick, 1928; Hammond, 1935). In addition, a positive correlation between fetal and placental weight has been reported for several species (Ibsen, 1928; Warwick, 1928; Hammond, 1935; McKeown \& Record, 
1953; Alexander, 1964a). These observations led Huggett \& Hammond (1952) to propose that "the size to which the fetal placenta grows during the early stages of pregnancy may determine, other things being equal, the amount of nutrition that is at the disposal of the fetus for growth during the later stages of pregnancy". However, Huggett \& Hammond (1952) also pointed out that this proposal may not be entirely valid since plancetal weight may not be indicative of placental function. Indeed, placental clearance of antipyrine, sodium, urea and $\mathrm{H}_{2} \mathrm{O}$ increases with gestational age in several species (Flexner \& Gellhorn, 1942; Meschia et al., 1966, 1967). In cows, transplacental diffusion of $\mathrm{H}_{2} \mathrm{O}$ not only increases with gestational age, but remains constant when expressed as $\mathrm{ml} \cdot \mathrm{min}^{-1} \cdot \mathrm{kg}$ fetus $^{-1}$ (Reynolds \& Ferrell, 1987). In the present study, DNA, RNA and protein concentrations of fetal placentomal tissues increased whereas those of maternal placentomal tissues remained constant from Day 100 to Day 250 of gestation. Because DNA, RNA and protein increased at about the same rates, growth of fetal placental tissues did not result from cellular or tissue hypertrophy, but rather from substantial hyperplasia. A portion of this hyperplasia may have resulted from increased density of vascular endothelial cells, which has been shown to occur primarily in fetal compared with maternal placentomal tissues of cows and ewes during late gestation (Hammond, 1927; Barcroft, 1946; Teasdale, 1976). In support of this proposal, umbilical blood flow and fetal $\mathrm{O}_{2}$ and glucose uptakes increased 20-fold whereas uterine blood flow and uterine $\mathrm{O}_{2}$ and glucose uptakes increased only 5-fold from mid- to late gestation in cows (Reynolds et al., 1986). Based upon these observations, it seems that, during the second half of gestation, fetal placental functional capacity increases at a greater rate than mass, due, in part, to hyperplasia of fetal placental tissues.

In the present study, the in-vitro rate of oxygen consumption by bovine placental tissues was similar to that reported by us and others for ovine placental tissues (Bell et al., 1987a; Reynolds \& Redmer, 1987). The large proportion of $\mathrm{O}_{2}$ taken up by the gravid uterus and utilized to support placental metabolism varies from $\approx 80 \%$ at mid-gestation to $\approx 40 \%$ during late gestation in cows and ewes (Battaglia \& Meschia, 1981; Bell et al., 1986; Reynolds et al., 1986). In addition, in-vivo studies have shown a relatively high rate of $\mathrm{O}_{2}$ consumption for the placenta compared with the fetus in cows $\left(0.46\right.$ versus $0.25 \mu \mathrm{mol} \cdot \mathrm{min}^{-1} \cdot \mathrm{g}^{-1}$; Reynolds et al., 1986) and ewes $(0.63$ versus $0.32 \mu \mathrm{mol} \cdot \mathrm{min}^{-1} \cdot \mathrm{g}^{-1}$; Meschia et al., 1966). In the present study, in-vitro uptake of $\mathrm{O}_{2}$ by maternal placental tissues was comparable to that reported for placental tissues in vivo and was 2-3-fold greater than $\mathrm{O}_{2}$ uptake of fetal placental tissues. Similar observations have been reported for sheep placental tissues (Reynolds \& Redmer, 1987). Therefore, maternal placental tissues probably account for a major portion of the high metabolic demand of the placenta. Intercaruncular endometrium, which is the site of uterine glands (Ramsey, 1982), exhibited a greater metabolic rate than did any of the other placental tissues. Uterine glands continue to develop throughout gestation in cows and ewes and secrete large amounts of histotrophe, thereby providing a portion of the nutritional demands of the fetus (Hammond, 1927; Bazer et al., 1979; Ramsey, 1982; L. P. Reynolds \& D. A. Redmer, unpublished observations), which may account for the high metabolic rate of intercaruncular endometrium. Fetal placental tissues had relatively low growth and metabolic rates, yet, as discussed above, probably continue to increase their functional capacity throughout gestation. Thus fetal placental tissues appear to provide for the metabolic demands of fetal growth while their own metabolic demands are minimal.

As further indication of the importance of uterine glandular secretions in supporting fetal growth, intercaruncular tissues exhibited a relatively high rate of production of macromolecules. Secretory activity of intercaruncular endometrium, however, decreased from Day 100 to Day 250 of gestation. Assuming that all non-dialysable $\left[{ }^{3} \mathrm{H}\right] \mathrm{leucine}$ was incorporated into macromolecules and that in-vitro secretory rate reflects secretory activity in vivo, decreased secretory activity of intercaruncular endometrium may indicate reduced importance of histotrophic secretion during late gestation. Uterine-specific proteins secreted by intercaruncular endometrium of cows throughout gestation may also have other functions in addition to providing for fetal nutrition (Bazer $\&$ First, 1983; Bartol et al., 1985a). Reynolds \& Redmer (1988) found that, from Day 100 to 250 of 
gestation, intercaruncular endometrium secreted a factor(s) which may regulate growth of blood vessels (angiogenesis) in the placenta. In contrast with intercaruncular tissues, intercotyledonary tissues increased their rate of secretion of macromolecules from Day 100 to 250 . The role of secretory products of the chorioallantois in gravid uterine function is not known. Bartol et al. (1985b) found a glycoprotein of high molecular weight (735000) secreted by bovine chorion up to Day 69 of gestation, but did not evaluate later stages and reported no function for this glycoprotein. Reynolds \& Redmer (1988) reported that intercotyledonary tissues also secreted a factor(s) which may modulate placental angiogenesis. Additionally, products of intercotyledonary chorioallantois may regulate growth of non-vascular components of placenta. That intercotyledonary tissues can affect endometrial function is indicated by the observation that 'adventitious placentomes', which are smaller and more diffuse than normal placentomes but exhibit similar arrangement of fetal and maternal tissues, frequently form in interplacentomal areas during late pregnancy in cows (Hammond, 1927; L. P. Reynolds \& D. A. Redmer, unpublished observations). Therefore, as stated by Hammond (1927), "it is apparent that the power, not only of developing the dormant caruncles of the uterus, but also of initiating the formation of new adventitious placentomal growths rests with the foetal membranes".

We thank C. T. Wold for technical assistance; D. W. Zaeske for assistance at slaughter; and J. Berg for typing the manuscript. Supported, in part, by PHS grant HD22559 to D.A.R. and L.P.R. Journal Article No. 1783 of the North Dakota Agricultural Experiment Station, Project 1782.

\section{References}

Alexander, G. (1964a) Studies on the placenta of the sheep. Placental size. J. Reprod. Fert. 7, 289-305.

Alexander, G. (1964b) Studies on the placenta of the sheep. Effect of surgical reduction in the number of caruncles. J. Reprod. Fert. 7, 307-322.

Anthony, R.V., Bellows, R.A., Short, R.E., Staigmiller, R.B., Kaltenbach, C.C. \& Dunn, T.G. (1986) Fetal growth of beef calves. II. Effect of sire on prenatal development of the calf and related placental characteristics. J. Anim. Sci. 62, 1375-1387.

Barcroft, J. (1946) Researches on Pre-natal Life. Thomas, Springfield.

Bartol, F.F., Roberts, R.M., Bazer, F.W., Lewis, G.S., Godkin, J.D. \& Thatcher, W.W. (1985a) Characterization of proteins produced in vitro by periattachment bovine conceptuses. Biol. Reprod. 32, 681-693.

Bartol, F.F., Roberts, R.M., Bazer, F.W. \& Thatcher, W.W. (1985b) Characterization of proteins produced in vitro by bovine endometrial explants. Biol. Reprod. 33, 745-759.

Battaglia, F.C. \& Meschia, G. (1981) Foetal and placental metabolisms: their interrelationship and impact upon maternal metabolism. Proc. Nutr. Soc. 40, 99-113.

Bazer, F.W. \& First, N.L. (1983) Pregnancy and parturition. J. Anim. Sci. 57 (Suppl. 2), 425-460.

Bazer, F.W., Roberts, R.M., Mahaboob Basha, S.M., Zavy, M.T., Caton, D. \& Barron, D.H. (1979) Method for obtaining ovine uterine secretions from unilaterally pregnant ewes. J. Anim. Sci. 49, $1522-1527$.

Bell, A.W., Kennaugh, J.M., Battaglia, F.C., Makowski, E.L. \& Meschia, G. (1986) Metabolic and circulatory studies of fetal lamb at midgestation. Am. J. Physiol. 250, E538-E544.

Bell, A.W., McBride, B.W., Vatnick, I. \& Early, R.J. (1987a) Total and $\mathrm{Na}^{+}, \mathrm{K}^{+}$-ATPase-dependent respiration in normal and growth-retarded sheep placenta. J. Anim. Sci. 65 (Suppl. 1), 24l, abstr.

Bell, A.W., Wilkening, R.B. \& Meschia, G. (1987) Some aspects of placental function in chronically heatstressed ewes. J. devl Physiol. 9, 17-29.

Eckstein, P., McKeown, T. \& Record, R.G. (1955) Variation in placental weight according to litter size in the guinea-pig. $J$. Endocr. 12, 108-114.

Enesco, M. \& Leblond, C.P. (1962) Increase in cell number as a factor in the growth of the organs and tissues of the young male rat. $J$. Embryol. exp. Morphol. 10, 530-562.

Ferrell, C.L. \& Reynolds, L.P. (1987) Blood flow and nutrient uptake of the gravid uterus, fetus and uteroplacenta of Hereford or Charolais cows bearing single or twin fetuses. J. Anim. Sci. 65 (Suppl. 1), 148, abstr.

Ferrell, C.L., Garrett, W.N. \& Hinman, N. (1976a) Growth, development and composition of the udder and gravid uterus of beef heifers during pregnancy. $J$. Anim. Sci. 42, 1477-1489.

Ferrell, C.L., Garrett, W.N., Hinman, N. \& Grichting, G. (1976b) Energy utilization by pregnant and nonpregnant heifers. J. Anim. Sci. 42, 937-950.

Flexner, L.B. \& Gellhorn, A. (1942) The comparative physiology of placental transfer. Am. J. Obstet. Gynecol. 43, 965-974.

Hammond, J. (1927) The Physiology of Reproduction in the Cow. Cambridge, London.

Hammond, J. (1935) The changes in the reproductive organs of the rabbit during pregnancy. Trans. Dynamics Develop., Moscow 10, 93-112.

Huggett, A.St.G. \& Hammond, J. (1952) Physiology of the placenta. In Marshall's Physiology of Reproduction, 3rd edn, Vol. II, p. 312-397. Ed. A. S. Parkes LengmansBGreen, Londen om at 04/26/2023 09:00:21AM 
Ibsen, H.L. (1928) Prenatal growth in guinea-pigs with special reference to environmental factors affecting weight at birth. J. exp. Zool. 51, 51-91.

Joubert, D.M. \& Hammond, J. (1958) A crossbreeding experiment with cattle with special reference to the maternal effect in South Devon-Dexter crosses. $J$. agric. Sci., Camb. 51, 325-341.

Kirk, R.E. (1968) Experimental Design: Procedures for the Behavioural Sciences. Wadsworth, Belmont.

Koong, L.J., Garrett, W.N. \& Rattray, P.V. (1975) A description of the dynamics of fetal growth in sheep. J. Anim. Sci. 41, 1065-1068.

Lowry, D.H., Rosebrough, N.J., Farr, A.L. \& Randall, R.J. (1951) Protein measurement with the Folin phenol reagent. J. biol. Chem. 193, 265-275.

McKeown, T. \& Record, R.G. (1953) The influence of placental size on foetal growth in man, with special reference to multiple pregnancy, $J$. Endocr. 9, 418-426.

Meschia, G., Battaglia, F.C. \& Bruns, P.D. (1967) Theoretical and experimental study of transplacental diffusion. J. appl. Physiol. 22, 1171-1178.

Meschia, G., Cotter, J.R., Makowski, E.L. \& Barron, D.H. (1966) Simultaneous measurement of uterine and umbilical blood flows and oxygen uptake. Quart. J. exp. Physiol. 52, 1-18.

Millaway, D.S., Redmer, D.A., Kirsch, J.D., Anthony, R.V. \& Reynolds, L.P. (1989) Angiogenic activity of maternal and fetal placental tissues of ewes throughout gestation. J. Reprod. Fert. 86, 689-696.

Prior, R.L. \& Laster, D.B. (1979) Development of the bovine fetus. J. Anim. Sci. 48, 1546-1553.

Ramsey, E.M. (1982) The Placenta, Human and Animal. Praeger, New York.

Rattray, P.V., Robinson, D.W., Garrett, W.N. \& Ashmore, R.C. (1975) Cellular changes in the tissues of lambs during fetal growth. J. Anim. Sci. 40, 783-788.

Reynolds, L.P. \& Ferrell, C.L. (1987) Transplacental clearance and blood flows of bovine gravid uterus at several stages of gestation. Am. J. Physiol. 253, R735-R739.
Reynolds, L.P. \& Ford, S.P. (1984) Contractility of the ovarian vascular bed during the oestrous cycle and early pregnancy in gilts. $J$. Reprod. Fert. 71, 65-71.

Reynolds, L.P. \& Redmer, D.A. (1987) Oxygen consumption of ovine placental tissues at several stages of gestation. J. Anim. Sci. 65 (Suppl. 1), 413, abstr.

Reynolds, L.P. \& Redmer, D.A. (1988) Secretion of angiogenic activity by placental tissues of cows at several stages of gestation. J. Reprod. Fert. 83, 497-502.

Reynolds, L.P., Ferrell, C.L., Nienaber, J.A. \& Ford, S.P. (1985a) Effects of chronic environmental heat stress on blood flow and nutrient uptake of the gravid bovine uterus and foetus. J. agric. Sci., Camb. 104, 289-297.

Reynolds, L.P., Ford, S.P. \& Ferrell, C.L. (1985b) Blood flow and steroid and nutrient uptake of the gravid uterus and fetus of sows. J. Anim. Sci. 61, 968-974,

Reynolds, L.P., Ferrell, C.L., Robertson, D.A. \& Ford, S.P. (1986) Metabolism of the gravid uterus, foetus and utero-placenta at several stages of gestation in cows. J. agric. Sci., Camb. 106, 437-444.

SAS User's Guide (1985) Statistics, 5th edn. Statistical Analysis System Institute, Cary, NC.

Teasdale, F. (1976) Numerical density of nuclei in the sheep placenta. Anat. Rec. 185, 187-196.

Umbriet, W.W., Burriss, R.H. \& Stauffer, J.F. (1972) Manometric \& Biochemical Techniques, 5th edn. Burgess, Minneapolis.

Wallace, L.R. (1948) The growth of lambs before and after birth in relation to the level of nutrition. Parts II and III. J. agric. Sci., Camb. 38, 243-302 and $367-401$.

Warwick, B.L. (1928) Prenatal growth of swine. $J$. Morphol. Physiol. 46, 59-84.

Wootton, R., McFayden, I.R. \& Cooper, J.E. (1977) Measurement of placental blood flow in the pig and its relation to placental and fetal weight. Biol. Neonate 31, 333-339.

Received 25 August 1989 